\title{
Evaluasi Metode Skrining Biofilm Enterococcus faecalis Isolat Klinik Kateter Urin
}

\author{
Wani Devita Gunardi ${ }^{1}$, Mohamad Yanuar Prasetyo Nugroho ${ }^{2}$, Elisabeth D. Harahap ${ }^{1}$ \\ ${ }^{1}$ Staf Pengajar Bagian Mikrobiologi Fakultas Kedokteran Universitas Kristen Krida Wacana \\ ${ }^{2}$ Mahasiswa Fakultas Kedokteran Universitas Kristen Krida Wacana \\ Alamat Korespondensi: wani_gunardi@ukrida.ac.id
}

\begin{abstract}
Abstrak
Laporan National Healthcare Safety Network dari tahun 2006 - 2008, menunjukan penyebab paling umum kedua infeksi saluran kemih (ISK) terkait kateter adalah genus Enterococcus setelah Eschericia coli. Pada infeksi saluran kemih terkait kateter urin, faktor yang berperan penting dalam patogenesis infeksi ini, yaitu: pembentukan biofilm pada kateter urin. Peranan Enterococcus faecalis sebagai penyebab infeksi saluran kemih berkaitan dengan kemampuannya dalam membentuk biofilm. Ada beberapa variasi metode untuk mendeteksi pembentukan biofilm seperti Tissue Culture Plate (TCP), Tube method (TM), dan Congo Red Agar (CRA). Tujuan penelitian ini untuk mendapatkan metode deteksi pembentukan biofilm dari E. faecalis yang tepat, cepat, dan mudah dilakukan. Total tigabelas isolat bakteri E. faecalis yang didapat dari hasil isolasi kultur kateter urin dilakukan uji deteksi pembentukan biofilm dengan metode TCP sebagai baku emas dan CRA sebagai pemeriksaan pembanding. Hasilnya, didapatkan $61,5 \%$ dan $69,2 \%$ bakteri $E$. faecalis mampu menghasilkan biofilm menggunakan metode TCP dan CRA. Hasil uji diagnostik metode CRA dibandingkan dengan metode TCP untuk deteksi pembentukan biofilm, didapatkan sensitivitas dan spesifisitas dari CRA sebesar $75 \%$ dan $40 \%$. CRA merupakan metode yang cepat dan mudah untuk dilakukan, namun memiliki spesifitas yang kurang baik. Hal ini dapat disebabkan pembacaan hasil yang bersifat subjektif dan menimbulkan kesalahan paralaks.
\end{abstract}

Kata kunci : Enterococcus faecalis, Kateter Urin, Biofilm.

\section{Evaluation of Screening Methods of Biofilm Formation in Enterococcus faecalis : Clinical Isolates from Urinary Catheter}

\begin{abstract}
According to 2006-2008 reports by The National Healthcare Safety Network, the genus Enterococcal was the second most common Catheter Associated Urinary Tract Infections (CAUTI) after Eschericia coli. The biofilm has an important role of the CAUTI pathogenesis. The role of Enterococcus faecalis in the etiology of urinary tract infection has been related to its ability to form biofilm. There are various methods to detect biofilm production, such as Tissue Culture Plate (TCP), Tube method (TM), and Congo Red Agar method (CRA). The goal of this study was to find the effective method to detect biofilm formation from E. faecalis. A total of thirteen E. faecalis bacterial isolates from catheter culture were subjected to the TCP and CRA methods for the detection the biofilm formation. By these methods, we obtained $61.5 \%$ and $69.2 \%$ of biofilm forming bacteria E. faecalis However, CRA method was more sensitive and specific when compared to the TCP (75\% to 40\%, respectively). The study concludes that the CRA method was rapid and simple for the detection of biofilm formation but the specificity was not good enough, probably due to subjective paralax reading of the results.
\end{abstract}

Keywords: Enterococcus faecalis, Urine Catheter, Biofilm 


\section{Pendahuluan}

Enterococci merupakan salah satu dari flora normal intestinal manusia dan hewan, namun mikroba ini juga penyebab penting infeksi nosokomial yang menginfeksi berbagai bagian tubuh dan dapat menyebabkan bakteremia. Dilaporkan oleh 152 rumah sakit di Amerika Serikat, bakteri ini berperan dalam infeksi nosokomial seperti infeksi peredaran darah ditemukan sebanyak $11 \%$, dan sebagai bakteri patogen terbanyak pada infeksi lokasi bedah ditemukan sebanyak $17 \%$. ${ }^{1}$ Selama dua dekade, angka kejadian infeksi nosokomial yang disebabkan bakteri Enterococcus sp meningkat. Hal ini dapat disebabkan penggunaan antibiotik yang berlebih, serta adanya faktor biofilm yang mendukung proses terjadinya pertukaran faktor determinan resisten antibiotik. ${ }^{2}$ Salah satu peranan dari biofilm adalah kemampuan resistensi bakteri dalam struktur biofilm meningkat sampai 1000 kali lebih resisten terhadap antibiotik daripada sel planktonik disebabkan beberapa mekanisme seperti difusi antibiotik yang terhambat akibat adanya matriks biofilm, pertukaran gen resisten antar bakteri dalam komunitas biofilm, kemampuan bakteri untuk memompa antibiotik keluar dari biofilm, perubahan suasana lingkungan dalam biofilm yang mempengaruhi $\mathrm{pH}$ lingkungan, kemampuan bakteri untuk mengubah target antibiotik dan pertumbuhan bakteri dalam biofilm menjadi cenderung lambat karena keterbatasan nutrisi sehingga beberapa antibiotik yang bekerja pada kondisi bakteri tumbuh cepat menjadi tidak peka lagi. ${ }^{3-5}$ Bakteri Enterococci faecalis mempunyai kemampuan untuk mengekspresikan protein pada permukaan yang memungkinkan kolonisasi dan pembentukan biofilm pada host itu sendiri. ${ }^{6}$ Menurut Barbara, biofilm berperan sebagai fokus utama dari patogenesis infeksi saluran kemih yang berkaitan dengan pemasangan kateter urin. ${ }^{7}$ Ada dua studi mengenai prevalensi bakteri penghasil biofilm yang menyimpulkan, bahwa mayoritas bakteri yang menghasilkan biofilm dari kateter urin adalah Enterococcus faecalis. ${ }^{8,9}$

Hasil produksi biofilm bakteri Enterococcus juga bervariasi pada banyak negara, seperti di United Kingdom (UK), dari 109 enterococcus hasil isolasi kateter pembuluh darah, didapatkan E. faecalis (100\%) dan E. faecium (50\%) menghasilkan biofilm. $^{10}$ Studi lain di Polandia menyimpulkan, $59 \%$ hasil isolasi E. faecalis dari saluran kemih dapat membentuk biofilm. ${ }^{11}$ Pada penelitian di Pakistan, didapatkan $75 \%$ produksi biofilm adalah uropatogen dari saluran kemih. Biofilm tersebut kebanyakan dideteksi dari bakteri $S$. aureus $(75 \%)$, E. faecalis $(75 \%)$, dan E. coli $(40 \%) .{ }^{12}$ Sedangkan di Jepang, semua 352 sampel E. faecalis dari infeksi saluran kemih dapat membentuk biofilm yang bersifat lemah, medium, atau kuat. ${ }^{13}$

Ada beberapa studi yang menyebutkan metode-metode untuk mendeteksi biofilm seperti Tissue Culture Plate (TCP) yang lebih baik dalam mendeteksi bakteri pembentuk biofilm dibandingkan dengan Congo Red Agar (CRA). ${ }^{8}, 14$ Penelitian sebelumnya banyak menggunakan model bakteri S.epidermidis yang sifat fenotifnya berbeda dari E.faecalis walaupun sama-sama merupakan bakteri kokus Gram positif. ${ }^{15}$ E.faecalis termasuk dalam genus Streptococcus (katalase negatif) berbeda genus dengan S.epidermidis (katalase positif). Metode CRA pernah dilakukan untuk skrining biofilm dari E.coli dan memberikan hasil yang cukup baik. ${ }^{16,17}$ Sampai saat ini, masih terdapat perdebatan metode mana yang paling efisien untuk mendeteksi biofilm dari berbagai jenis bakteri. Deteksi biofilm terhadap Enterococcus telah dilakukan menggunakan metode TCP tetapi perbandingannya dengan metode CRA belum pernah dilakukan. Ada dua studi mengenai metode Congo Red Agar (CRA) yang telah dilakukan, hasilnya metode ini cukup sederhana, mudah, murah, dan penilaiannya cepat, namun hasilnya hanya dapat dinilai berdasarkan analisis visual yang bersifat kualitatif dan mengandalkan visual subjektif. ${ }^{8,15,17}$ Pada penelitian ini ingin menguji, apakah metode CRA dapat digunakan untuk uji deteksi biofilm dari bakteri Enterococcus faecalis hasil isolat kateter urin. Pada beberapa penelitian, hanya membandingkan antar metode deteksi biofilm dan TCP adalah metode yang paling baik dibandingkan metode tube method dan CRA tanpa hasil sensitifitas dan spesifitas dari masing-masing metode deteksi biofilm. ${ }^{14,18}$

\section{Metode Penelitian}

Desain penelitian yang digunakan adalah desain penelitian observasional, untuk 
mengetahui kemampuan pembentukan biofilm dari tiga belas bakteri Enterococcus faecalis hasil isolat kateter urin yang diidentifikasi menggunakan Vitek2 (Biomeriux). Sampel kateter urin diambil pada periode Agustus 2016- November 2016 di rumah sakit swasta Tangerang. Isolat Enterococcus dibuat dalam stok kultur dan disimpan pada suhu $-80^{\circ} \mathrm{C}$. Penelitian ini dilakukan di laboratorium FK Ukrida, mulai dari Bulan Agustus 2017 Oktober 2017.

\section{Metode Congo Red Agar (CRA) $)^{15,19}$}

Medium agar pada metode ini mengandung Brain heart infusion broth (37 gr/L), sukrosa (50 gr/L) dan agar no.1 (10 gr/L) dan pewarna Congo red (8 gr/L). Pewarna Congo red dilarutkan dengan aquadest pada Erlenmeyer yang berbeda, dan keduanya dilakukan proses sterilisasi dengan autoklaf $\left(121^{\circ} \mathrm{C}\right.$ untuk 15 menit) secara terpisah. Larutan pewarna Congo red kemudian dicampurkan kedalam Brain heart infusion agar dengan sukrosa pada $55^{\circ} \mathrm{C}$. Tiap pelat CRA kemudian diinokulasikan dengan masing-masing tiga belas bakteri Enterococcus faecalis dan diinkubasi selama 24 jam pada $37^{\circ} \mathrm{C}$. Strain yang memiliki kemampuan membentuk biofilm akan nampak sebagai koloni berwarna hitam, sedangkan strain yang tidak memiliki kemampuan membentuk biofilm akan nampak sebagai koloni berwarna merah. Kontrol negatif pada penelitian ini menggunakan CRA steril, sedangkan kontrol positif digunakan bakteri E. Coli ATCC e35218. Metode ini dilakukan dengan tiga kali pengulangan.

\section{Metode Tissue Culture Plate (TCP) $)^{20-22}$}

Tiap tabung reaksi berisikan $10 \mathrm{ml}$ Luria-bertani broth (25 gr/L) diinokulasikan dengan masing-masing tiga belas bakteri Enterococcus faecalis dan diinkubasi selama 24 jam pada $37^{\circ} \mathrm{C}$. Suspensi bakteri kemudian dibuat dengan standar $0,5 \mathrm{McF}$ arland $\left(1,5 \times 10^{8}\right.$ suspensi bakteri / $\mathrm{mL}$ ) dan masing-masing bakteri diencerkan 1:11 menggunakan Luriabertani broth (LBB) steril kedalam tiap sumur tissue culture plate flat bottom. Pada metode ini, LBB steril digunakan sebagai kontrol negatif. Suspensi dalam pelat kemudian diinkubasi selama 48 jam pada $37^{\circ} \mathrm{C}$. Setelah inkubasi selesai, buang suspensi dengan cara membalik pelat secara cepat lalu berikan aquadest sebanyak $200 \mu$ liap sumurnya, balik kembali pelat dan tunggu pelat sampai mengering. Berikan tiap sumur larutan kristal violet $0,1 \%$ sebanyak $100 \mu l$ selama 15 menit. Larutan kristal violet kemudian dibuang dengan cara membalik microplate secara cepat, lalu tiap sumur dicuci lagi menggunakan aquadest sebanyak $200 \mu$ tiap sumurnya. Setelah dilakukan pencucian, mikroplat dikeringkan sampai sama dengan temperature ruangan. Setelah mikroplate kering, berikan etanol 96\% sebanyak 150 $\mu 1$, kemudian mikroplate harus ditutup untuk mengurangi penguapan, dan kemudian akan dibaca menggunakan ELISA plate reader pada panjang gelombang $595 \mathrm{~nm}$. Metode ini dilakukan dengan tiga kali pengulangan, dan nilai rata-rata Optical densities (OD) dari ketiganya akan diambil sebagai nilai hasil. Nilai OD ini akan menentukan ada tidaknya biofilm dan derajat kemampuannya dalam membentuk biofilm yaitu tidak membentuk, lemah, sedang dan kuat.

\section{Hasil Penelitian}

Hasil penelitian menunjukkan sebanyak 8 strain isolat $(61,5 \%)$ dari total 13 isolat terdeteksi biofilm menggunakan metode TCP sebagai baku emas sedangkan dengan metode CRA mendeteksi sebanyak $9(69,2 \%)$ strain merupakan penghasil biofilm dari 13 isolat $E$. faecalis.

CRA merupakan metode yang dilakukan untuk melihat karakteristik fenotip bakteri pada media CRA. Hasil yang didapatkan berupa data kualitatif berupa warna yang berbeda pada koloni. Pada Gambar 1 . menunjukkan warna koloni yang dihasilkan pada metode CRA, ada kesulitan menentukan interpretasi hasil berdasarkan warna koloni dikarenakan terdapat kemiripan warna dan bersifat subyektif. 


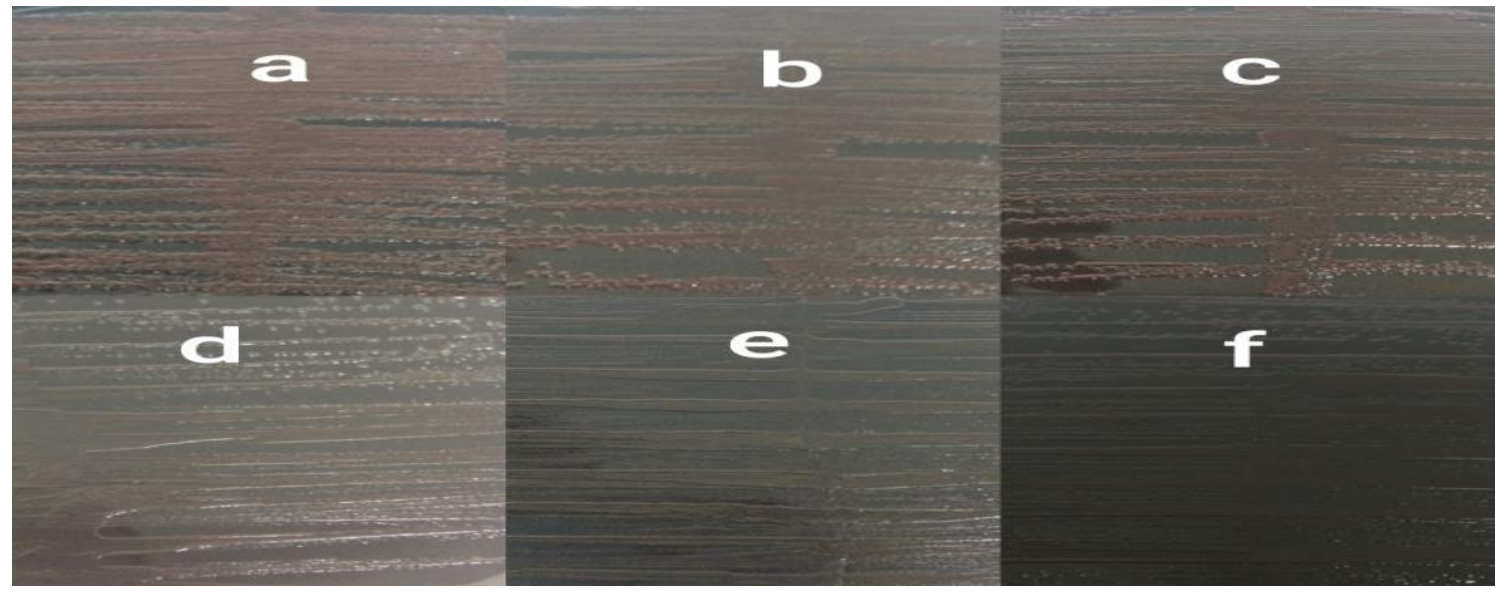

Gambar 1. Warna Koloni Bakteri E. faecalis. (a),(b),(c) ; Warna Koloni Merah, Koloni non-Penghasil Biofilm; (d), (e), (f) ; Warna Koloni Hitam, Koloni Penghasil Biofilm.

Tabel 1. Interpretasi Tiga Belas Isolat E. faecalis Berdasarkan OD dari ELISA Plate Reader

Hasil Tissue Culture Plate

\begin{tabular}{cccc}
\hline Formula & Pembentuk Biofilm & Perhitungan Jarak OD & Jumlah Isolat \\
\hline OD $<$ ODc & Non-Biofilm & $<0,462$ & $5(38,5 \%)$ \\
OD $>$ ODc & Lemah & $0,462-0,924$ & $5(38,5 \%)$ \\
OD $<$ 2ODc & Sedang & $0,924-1,848$ & $3(23 \%)$ \\
OD $>$ 2ODc & Kuat & $>1,848$ & $0(0 \%)$ \\
OD $>$ 4ODc & KODc & & \\
\hline
\end{tabular}

Pada Tabel 1. dijabarkan formula interpretasi hasil dari metode TCP menurut kriteria dari Ibrišimović et al untuk membagi biofilm yang bersifat lemah, sedang, dan kuat. $^{20}$ Hasil penelitian dengan menggunakan metode ini didapatkan bakteri E. faecalis sebagai penghasil biofilm bersifat sedang, lemah dan tidak menghasilkan biofilm secara berurutan sebanyak 5 (38,5\%), 3 (23\%) dan 5 $(38,5 \%)$. Pada penelitian ini, tidak didapatkan pembentuk biofilm yang kuat dikarenakan tidak ada nilai OD tidak melebihi empat kali ODc.

Tabel 2. Hasil Uji Diagnostik dari Hasil Metode CRA dengan Metode TCP

\begin{tabular}{cllll}
\hline & & \multicolumn{3}{c}{ Metode TCP } \\
\hline \multirow{3}{*}{ Metode } & CRA $(+)$ & TCP $(+)$ & TCP $(-)$ & Jumlah \\
CRA & CRA (-) & $2(\mathrm{a})$ & $3(\mathrm{~b})$ & 9 \\
& Jumlah & 8 & $2(\mathrm{~d})$ & 4 \\
& & 5 & 5 & 13 \\
\hline
\end{tabular}


Hasil uji diagnostik untuk melihat nilai sensitivitas dan spesitivitas dari metode CRA dengan pembanding metode TCP sebagai baku emas, adalah sebesar 75\% dan 40\% (Tabel 2).

Tabel 3. Perbandingan Hasil Uji Deteksi Pembentukan Biofilm dari Metode TCP dan CRA (+)

\begin{tabular}{ccc}
\hline Klasifikasi biofilm & \multicolumn{2}{c}{ Uji Deteksi Biofilm } \\
& TCP & CRA $(+)$ \\
\hline Kuat & 0 & 0 \\
Sedang & $0 \%$ & $0 \%$ \\
& 3 & 3 \\
Lemah & $23 \%$ & $23 \%$ \\
& 5 & 3 \\
Non-Biofilm & $38,50 \%$ & $23 \%$ \\
& 5 & 3 \\
& $38,50 \%$ & $23 \%$ \\
\hline
\end{tabular}

\section{Pembahasan}

Dari hasil penelitian ini, metode CRA dengan nilai sensitivitas sebesar $75 \%$ dapat digunakan untuk mendeteksi adanya pembentukan biofilm dari bakteri Enterococcus faecalis dan direkomendasikan sebagai metode skrining uji pembentukan biofilm. Hasil ini sesuai dengan penelitian sebelumnya dari Rajkumar yang menguji151 isolat klinik. ${ }^{23}$ Keterbatasan metode CRA adalah tidak dapat menentukan derajat kekuatannya (lemah, sedang, dan kuat) seperti metoda TCP. Metode CRA ini tidak dapat mendeteksi pembentukan biofilm pada semua isolat yang kemampuan membentuk biofilm termasuk derajat lemah. Enterococcus faecalis memiliki kemampuan untuk meragi gula-gula seperti glukosa dan laktosa. Hasil metabolit peragian ini dibutuhkan untuk berikatan dengan Congo red membentuk koloni warna hitam. Pada strain Enterococcus faecalis yang memiliki kemampuan pembentukan biofilm yang lemah dapat terdeteksi oleh metode TCP karena pada metode ini, media pertumbuhannya ditambahkan glukosa $1 \%$ yang akan membantu pembentukan biofilm melalui metabolit peragian gula-gulanya. Bakteri E. faecalis memiliki ekstraselular matriks yang terdiri dari polisakarida, DNA, dan protein. CRA merupakan metode yang dapat mendeteksi karakteristik polisakarida dari pembentukan biofilm E. faecalis, namun CRA hanya mampu mendeteksi ada tidaknya pembentukan biofilm tanpa dapat mendeteksi derajat kemampuannya. Hal ini memperlihatkan hasil negatif pada CRA masih terdapat kemungkinan adanya kemampuan membentuk biofilm dengan derajat lemah. Artinya pada bakteri yang mempunyai kemampuan membentuk biofilm yang lemah belum tentu dapat terdeteksi dengan metoda CRA. Kelemahan lainnya adalah kesalahan paralaks mata saat menginterpretasikan hasil pada isolat yang seharusnya negatif menjadi positif. Hal ini menunjukkan metode CRA sensitif untuk mendeteksi penghasil biofilm derajat sedang dan kuat, namun pada pembentuk biofilm derajat lemah sensitivitas dari CRA menurun.

Banyak faktor untuk membuat struktur biofilm melekat pada suatu permukaan, salah satunya adalah lingkungan fisik dan kimia serta letak perlekatan biofilm memiliki dampak yang sangat besar terhadap pembentukan biofilm. ${ }^{23}$ Pantanella et al. menyebutkan, kondisi lingkungan tempat pertumbuhan biofilm merupakan faktor penting yang dapat mempengaruhi lepas atau tidaknya sel bakteri dari tempat perlekatannya. $^{24}$

Pada sisi lainnya, metode CRA merupakan metode yang mudah, cepat, dan murah untuk dilakukan. Metode ini merupakan metode agar media dan tidak membutuhkan alat untuk pembacaannya, namun cara pembacaannya menjadi titik lemah faktor human error yang merupakan kekurangan metode CRA. Hasil sensitivitas 75\% memperlihatkan bahwa metode CRA dapat digunakan hanya untuk skrining dan dapat membantu skrining biofilm pada fasilitas yang 
terbatas. Pada TCP, dibutuhkan waktu yang lebih banyak daripada metode CRA (CRA membutuhkan waktu 24 jam, TCP membutuhkan 48 jam). Kekurangan TCP sendiri ada pada cara kerja yang membutuhkan ketrampilan khusus untuk mengerjakan metoda ini.

\section{Simpulan}

Hasil Penelitian memperlihatkan sebesar $61,4 \%$ bakteri E. faecalis hasil isolat kateter urin membentuk biofilm dengan metode TCP sebagai baku emas, namun untuk pelaksanaannya diperlukan waktu, ketrampilan dan alat khusus.

CRA merupakan metode yang murah, cepat, dan mudah untuk dilakukan. Adanya kesulitan pembacaan hasil yang bersifat subjektif membuat CRA memiliki kekurangan dan berakibat pada pembacaan hasil yang kurang sensitif. Dari hasil uji diagnostik didapatkan nilai sensitivitas dan spesifisitas dari metode CRA sebesar $75 \%$ dan $40 \%$, sehingga metode CRA dapat dipakai sebagai uji skrining deteksi pembentukan biofilm pada bakteri Enterococcus faecalis.

\section{Daftar Pustaka}

1. Richards MJ, Edwards JR, Culver DH, Gaynes RP, System NNIS. Nosocomial infections in combined medical-surgical intensive care units in the United States. Infection Control \& Hospital Epidemiology. 2000;21(8):510-5.

2. Garsin DA, Frank KL, Silanpää J, Ausubel FM, Hartke A, Shankar N, et al. Pathogenesis and models of enterococcal infection. 2014.

3. R.M. D. Biofilm formation: A clinically relevant microbiological process. Clinical infectious disease: an official publication of the infectious diseases society of America 2001;33(1):1387-92.

4. R.M. D. Biofilms and device-associated infections. Emerging Infectious Diseases. 2001;7(2):277-81.

5. S.M. S. Importance of biofilm in urinary tract infections: New therapeutic approaches. Hindawi Publishing Corporation. 2014;13.

6. Pinkston KL, Gao P, Diaz-Garcia D, Sillanpää J, Nallapareddy SR, Murray $\mathrm{BE}$, et al. The Fsr quorum-sensing system of Enterococcus faecalis modulates surface display of the collagen-binding MSCRAMM Ace through regulation of gelE. Journal of Bacteriology. 2011; 05026-11.

7. Trautner BW, Darouiche RO. Role of biofilm in catheter-associated urinary tract infection. American Journal of Infection Control. 2004;32(3):177-83.

8. Hassan A. UJ, Kaleem F., Omair M., Khalid A., Iqbal M. Evaluation of different detection methods of biofilm formation in clinical isolates. Braz Journal Infect Dis. 2011;15(4):305-11.

9. Donlan R, Murga R, Bell M, Toscano C, Carr J, Novicki T, et al. Protocol for detection of biofilms on needleless connectors attached to central venous catheters. Journal of Clinical Microbiology. 2001;39(2):750-3.

10. Mohamed JA, Huang DB. Biofilm formation by enterococci. Journal of Medical Microbiology. 2007;56(12):1581-8.

11. Dworniczek E, Wojciech L, Sobieszczanska B, Seniuk A. Virulence of enterococcus isolates collected in lower silesia (Poland). Scandinavian Journal of Infectious Diseases. 2005;37(9):630-6.

12. Baqai R, Aziz M, Rasool G. Urinary tract infections in diabetic patients and biofilm formation of uropathogens. Infect Dis J Pak. 2008;17(1):21-4.

13. Seno $\mathrm{Y}$, Kariyama R, Mitsuhata R, Monden K, Kumon H. Clinical implications of biofilm formation by Enterococcus faecalis in the urinary tract. Acta Med Okayama. 2005;59(3):79-87.

14. Mathur T. SS, Khan S., Upadhyay DJ., Fatma T., Rattan A. Detection of biofilm formation among the clinical isolates of Staphylococci: an Evaluation of three different screening methods. Indian Journal Of Medical Microbiology. 2006;24(1):25-9.

15. Kaiser TDL, Pereira EM, dos Santos KRN, Maciel ELN, Schuenck RP, Nunes APF. Modification of the congo red agar method to detect biofilm production by Staphylococcus epidermidis. Diagnostic Microbiology and Infectious Disease. 2013;75(3):235-9.

16. Tajbakhsh E, Ahmadi P, AbedpourDehkordi E, Arbab-Soleimani N, 
Khamesipour F. Biofilm formation, antimicrobial susceptibility, serogroups and virulence genes of uropathogenic E. coli isolated from clinical samples in Iran. Antimicrobial resistance and infection control. 2016;5:11.

17. Neupane S, Pant ND, Khatiwada S, Chaudhary R, Banjara MR. Correlation between biofilm formation and resistance toward different commonly used antibiotics along with extended spectrum beta lactamase production in uropathogenic Escherichia coli isolated from the patients suspected of urinary tract infections visiting Shree Birendra Hospital, Chhauni, Kathmandu, Nepal. Antimicrobial Resistance and Infection Control. 2016;5:5.

18. Cremet L, Corvec S, Batard E, Auger M, Lopez I, Pagniez F, et al. Comparison of three methods to study biofilm formation by clinical strains of Escherichia coli. Diagnostic Microbiology and Infectious Disease. 2013;75(3):252-5.

19. Freeman D, Falkiner F, Keane C. New method for detecting slime production by coagulase negative staphylococci. Journal of Clinical Pathology. 1989;42(8):872-4.
20. Ibrisimovic MA. IM, Mehmedinovic NI., Hukic M. A Novel Spectrophotometric Assay for the determination of biofilm forming capacity of causative agents of urinary tract infections. International Journal of Engineering Research \& Technology. 2017;6(04):1225-30.

21. Christensen GD, Simpson WA, Bisno $\mathrm{AL}$, Beachey EH. Adherence of slimeproducing strains of Staphylococcus epidermidis to smooth surfaces. Infection and Immunity. 1982;37(1):318-26.

22. Naves P, Del Prado G, Huelves L, Gracia M, Ruiz V, Blanco J, et al. Measurement of biofilm formation by clinical isolates of Escherichia coli is method-dependent. Journal of Applied Microbiology. 2008;105(2):585-90.

23. Rajkumar H, Devaki R, Kandi V. Evaluation of different phenotypic techniques for the detection of slime produced by bacteria isolated from clinical specimens. Cureus. 2016;8(2).

24. Pantanella F, Valenti $P$, Natalizi $T$, Passeri D, Berlutti F. Analytical techniques to study microbial biofilm on abiotic surfaces: pros and cons of the main techniques currently in use. Ann Ig. 2013;25(1):31-42. 